\title{
Challenges of Implementing E-Learning in Kenya: A Case of Kenyan Public Universities
}

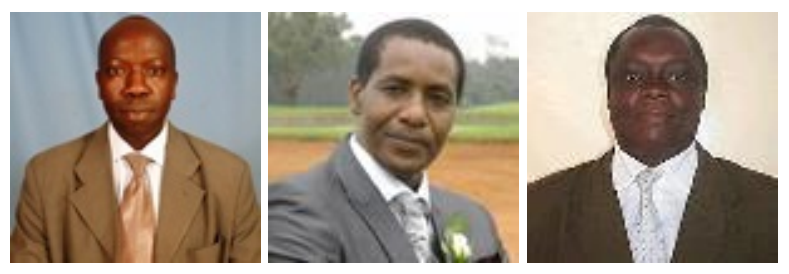

John K. Tarus ${ }^{1}$, David Gichoya ${ }^{1}$, and Alex Muumbo ${ }^{2}$ ${ }^{1}$ Moi University, Kenya, ${ }^{2}$ Technical University of Kenya

\begin{abstract}
In this paper, we discuss the challenges experienced by Kenyan public universities in implementation of e-learning and recommend possible solutions towards its successful implementation. In the last few years, most Kenyan public universities have adopted e-learning as a new approach to teaching and learning. However, the implementation challenges faced by these universities have continued to impact negatively on its effective utilization. This paper presents the findings from a survey of 148 staff of three Kenyan public universities who are currently using e-learning in blended mode approach. The purpose of this study was to investigate the challenges hindering the implementation of e-learning in Kenyan public universities. Data was collected through questionnaires, in-depth interviews and document analysis. The findings reveal that elearning comes with some challenges that must be addressed by Kenyan public universities before successful implementation can be realized. However, the benefits and opportunities presented by e-learning far outweigh the challenges. The paper finally recommends some possible solutions that public universities could embrace towards successful implementation of e-learning.
\end{abstract}

Keywords: e-learning; blended learning; online learning; ODL; challenges; higher education; Kenya 


\section{Introduction}

E-learning refers to learning facilitated and supported through the use of information and communications technology (Jenkins and Hanson, 2003). On the other hand, Garrison (2011) defines elearning as "electronically mediated asynchronous and synchronous communication for the purpose of constructing and confirming knowledge." E-learning can be considered a natural evolution of distance learning, which has always taken advantage of the latest tools to emerge in the context of technologies for structuring education (Sangrà et al., 2012). E-learning can be classified into two broad categories, synchronous and asynchronous (Cantoni, 2004). Synchronous learning uses a learning model that initiates a classroom course, lecture or meeting using Internet technologies. In synchronous learning, the interaction is live; it requires all the participants to be available at the same time. Asynchronous learning is described as a web-based version of computer-based training (CBT), which is typically offered on a CD-ROM or across an organization's local area network. The learner can access the course at any time at his or her own pace (Takalani, 2008).

New technologies including information communication technology (ICT) and e-learning have become the driving forces in most institutions including universities today. However, Balci and Soran (2009) point out that when 'ICT' and 'e-learning' were almost all set to be acknowledged by most educators as a savior, its limitations have also started surfacing and now the call is for 'blended learning'. Garrison and Vaughan (2008) define blended learning as "the thoughtful fusion of face-to-face and online learning experiences". Currently many institutions are opting for the blended learning delivery of courses (Stubbs, Martin, \& Endlar, 2006). Research conducted in many schools in Kenya has established that most of them are not effectively adopting and using ICT to support learning, teaching and management as intended (Manduku, Kosgey, \& Sang, 2012). Though many universities have adopted blended learning as a starting point due to lack of adequate e-learning skills and infrastructure, full implementation of elearning will offer numerous benefits to universities. According to Takalani (2008), e-learning adds the benefit of encouraging learners to take responsibility for their learning and build self-knowledge and selfconfidence. Other studies have shown that adoption and use of e-learning in schools can promote collaborative, active and lifelong learning, increase students' motivation, offer better access to information and shared working resources, deepen understanding, help students think and communicate creatively (Khan, Hasan \& Clement, 2012).

There are numerous challenges to overcome when implementing e-learning in universities. According to Salmon (2004), focusing training on the technological features of the e-learning system is only the first step to success; the real challenge is training for changes to pedagogy. Blinco et al. (2004) articulate that e-learning's success rests on the fundamental requirement that instructors and students possess adequate technical skills to use e-learning tools effectively. According to Tarus (2011), implementation of e-learning is still at the infancy stage in most Kenyan public universities due to many challenges related to implementation. These challenges range from technological, organisational and pedagogical challenges.

This work is licensed under a $\underline{\text { Creative Commons Attribution } 4.0 \text { International License. }}$ 
Universities that are planning to implement e-learning in their institutions should be prepared to respond to the challenges that are likely to arise in the course of implementation. Kenyan universities are being compelled by the government within the framework of Kenya Vision 2030 to introduce e-learning and blended learning as an alternative delivery system to increase accessibility to higher education in Kenya (NESC, 2007). Kenya Vision 2030 is the nation's new development blueprint for 2008 to 2030 which aims at making Kenya a newly industrializing, "middle income country providing high quality life for all its citizens by the year 2030". Full implementation of e-learning at university levels is considered as a long term strategy in Kenya Vision 2030. Implementation of e-learning alongside other strategies for education in Kenya Vision 2030 is anticipated to address the strategic areas, namely, access, quality, equity, technology and innovation. The vision for the education sector for 2030 is "to have globally competitive quality education, training and research for sustainable development" (NESC, 2007).

As a result, e-learning initiatives have been introduced in Kenyan public universities in line with the government's policy requiring universities to introduce e-learning as an alternative delivery system. From a survey visit by the researcher to a number of Kenyan universities, there was clear evidence that most of the universities are already using e-learning but mostly in blended mode with face to face teaching. At the University of Nairobi for instance, implementation of e-learning started in 2004 with a well tested e-learning platform called Wedusoft (a framework of Chisimba). Kenyatta University launched the e-learning mode of teaching in 2005 and is currently using Moodle as an e-learning platform. E-learning programmes have also been in operation at J omo Kenyatta University of Agriculture and Technology since 2006 with Moodle as an e-learning platform. Implementation of e-learning in Moi University started in 2007 with MUSOMI (customized from Chisimba framework) as an e-learning platform. However, a critical review of the tangible steps made reveals meager progress in utilization of e-learning approach in these public universities due to unforeseen challenges. Most of these universities are using elearning in blended mode and have lagged behind in full implementation.

In this paper we present the findings from a study to investigate the challenges hindering the implementation of e-learning in Kenyan public universities. The study involved gathering information from key e-learning stakeholders in three Kenyan public universities about their perceptions and experience on what challenges public universities face in implementation of elearning. The paper has also recommended possible solutions to overcome these challenges.

\section{Related Work}

E-learning is becoming an increasingly popular emerging new approach to teaching and learning in most institutions of higher learning worldwide. As Li and Hart (1996) and Lin (2006) pointed out, e-learning is becoming more and more popular with learners as they can combine their learning experience together with the advancement of information technology. ICT technologies

This work is licensed under a Creative Commons Attribution 4.0 International License. 
provide a distinct advantage to e-learning by revolutionizing every aspect of the learning. Wanjala, Khaemba and Mukwa (2011) advise institutions to adopt ICT utilization in education because these technologies have been recognized worldwide as tools that facilitate and enhance the teaching and learning process through various ways like providing universal access to learning resources. Adoption and use of ICT in schools can promote collaborative, active and lifelong learning, increase students' motivation, offer better access to information and shared working resources, deepen understanding, help students think and communicate creatively (Khan, Hasan \& Clement, 2012). Ariwa and Rui (2005) point out that e-learning has become the protagonist for change in education sector. Thus, stark ultimatums continue to be made by education technologists that universities must either 'transform or die' in the face of technological progress (Bates, 2004). Berhanu (2010) points out that promoting e-learning provides a potential and comparative ladder for developing countries to leapfrog to the knowledge economy. It is seen as a cost effective approach to facilitating learning to large groups using information and communication technology.

\section{Benefits of E-Learning}

The benefits of e-learning are mainly the cost efficiency, accessibility and flexibility in terms of time and place. E-learning allows learning to take place when the lecturer and the learner are separated both in time and space (Uys, 2003). It offers convenience for both tutor and the learner (learning anytime or anywhere). Other benefits of elearning as adapted and shortened from Unwin (2008) include:

- Ease of access to information,

- The potential for interactivity amongst and between learners and teachers,

- Enables conduct of lessons from a remote location and extends geographical access to education,

- Content is more timely, consistent and dependable with potential for re-use,

- Combination of both synchronous and asynchronous learning,

- Supports student centered e-learning paradigm and students can learn at their own pace,

- Increases access to learning and training opportunity,

- E-learning lowers costs and improves cost-effectiveness of educational resources,

- Offers the combination of education with work and family life,

- Scalability: e-learning solutions are highly scalable,

- Facilitates the management of student records and tracking students' progress. This work is licensed under a Creative Commons Attribution 4.0 International License. 


\section{Implementation of E-Learning}

Implementation of e-learning in universities should be viewed as part of educational reform. For e-learning to be efficient and effective, a great deal of care and attention needs to go into its implementation. According to Cox (2010), if e-learning is to be successfully adopted in a school, teachers and head teachers need to be involved in the decision making processes. Leadership and support from senior management are identified as critical factors for successful implementation (Birch \& Burnett, 2009; Browne et al., 2010). Gunawardena (2005) points out that for e-learning to succeed in the developing world, it needs to build on another important pillar: the existence of infrastructure, along with connectivity. Developing countries like Kenya still face a lot of challenges while implementing e-learning which requires advanced level of technological infrastructure and heavy investment of resources especially at the initial stages. Most of the Kenyan public universities rely on government exchequer for funding which has been dwindling in the recent years. According to Zake (2009), poverty is one of the most important barriers, especially due to the fact that ICT is important and therefore relatively more expensive in Africa than in developed countries. Therefore, most of the Kenyan public universities have opted for blended learning as a starting point since it's a cheaper option in terms of implementation and requirements. Research shows that teachers and learners prefer the blended learning approach, which mixes the traditional face-to-face teaching with online collaboration (Motteram, 2006). It is considerably clear that Kenyan public universities have taken significant steps and have shown their commitment towards implementation of elearning. According to the E-Readiness Survey of Kenyan Universities (2013) Report, Kenyan universities are allocating an average of $0.5 \%$ of their total recurrent expenditures on Internet bandwidth to support implementation of e-learning. As a result, the universities in 2013 achieved Internet bandwidth increase to $4.0 \mathrm{Mb} / \mathrm{s}$ per 1,000 students compared to only $0.431 \mathrm{Mb} / \mathrm{s}$ per 1,000 students in 2008 (Kashorda and Waema, 2014). However, their efforts towards full utilization of e-learning as an alternative approach to teaching and learning still faces other numerous obstacles which range from technological, organizational and pedagogical challenges. Berhanu (2010) warn that introduction of e-learning without acknowledging the paradigm shift and setting up the required ICT infrastructure and efficient support mechanism threatens e-learning developments.

The review of literature related to challenges of implementation of e-learning has revealed that a number of related studies have been carried out in other developing countries. For instance, Ssekakubo, Suleman and Marsden (2011) point out that majority of e-learning initiatives implemented in Sub-Saharan countries tend to fail, partially or totally due to various barriers to e-learning in developing countries. The absence or inadequacy of infrastructure is a barrier to access among students in developing countries. Touray, Salminen and Mursu (2013) identified 43 ICT barriers in developing countries that were grouped into eight possible critical success factors, namely socio-cultural, infrastructural, political and leadership, legal and regulatory, economical, educational and skills, security and safety and technical. In Saudi Arabia, according to Al-Ghaith, Sanzogni and Sandhu (2010), the quality of the Internet was an important factor influencing the adoption and usage of e-learning. Nawaz et al. (2011) identified the following factors as having an

This work is licensed under a Creative Commons Attribution 4.0 International License. 
impact on e-learning development at university level in Pakistan: teachers' ability to integrate technology into teaching and learning activities, development approaches and attitudes, project management techniques, user participation, user training, change management. Similarly, Libyan higher institutions still face many challenges in terms of the implementation of ICT and elearning in teaching and learning. These challenges are associated with the cultural and linguistic background of students and instructors, and their awareness of and attitudes towards e-learning; the underdeveloped technological infrastructure and the often prohibitive cost of educational technologies; the lack of local expertise in curriculum development for e-learning; and, the lack of educational management mechanisms to support e-learning initiatives (Rhema and Miliszewska, 2010). Oye et al. (2011) point out that aspects such as electricity, awareness and training of staff on the use of ICTs, motivation, bandwidth and Internet connectivity impacted on e-learning development at the university level in Nigeria. It is evident that some of the challenges of implementation of e-learning in developing countries are similar, some are unique to particular countries. Nawaz and Kundi (2010) caution that e-learning solutions must be compatible with the human and contextual factors of any country. Tedre et al. (2009) assert that no two developing countries are alike.

\section{Status of ICT Infrastructure in Kenyan Universities}

The Government of Kenya has over the years improved the regulatory environment to promote growth of the ICT sector and increase availability of broadband Internet in the country. In 1999, the government established the Kenya Education Network Trust (KENET), a National Research and Education Network that promotes the use of ICT in Teaching, Learning and Research in Higher Education Institutions in Kenya. The main aim of KENET is to interconnect all the universities, tertiary and research Institutions in Kenya by setting up a cost effective and sustainable private network with high speed access to the global Internet. KENET currently provides Internet bandwidth to 90 member institutions and 150 campuses, including all large research institutions in Kenya.

According to Kashorda and Waema (2014) in their E-Readiness Survey of Kenyan Universities (2013) Report, the networked PCs available per 100 students ratio was 3.8 in Kenyan universities, which was considered quite low. The e-readiness survey also indicated that 16,174 student lab computers were available for 423,664 students at the 30 universities and only $17 \%$ of students accessed computers from their campuses. On the other hand, 53\% of students owned over 200,000 laptop computers in the 30 universities. It was therefore recommended in the report that universities should invest in student computer labs to serve the students who are unable to purchase laptop computers or those who may not wish to carry their laptop computers to university campuses. The e-readiness survey further revealed that universities in 2013 achieved Internet bandwidth of $4.0 \mathrm{Mb} / \mathrm{s}$ per 1,000 students compared to only $0.431 \mathrm{Mb} / \mathrm{s}$ per 1,000 students in 2008.

The E-Readiness Survey (2013) Report however pointed out that although all universities are inter-connected to the national fiber backbone network, universities are not investing sufficiently

This work is licensed under a Creative Commons Attribution 4.0 International License. 
in their internal campus backbone and wireless network infrastructure that will make it easier for students to use their own laptops and smartphones on campus to access learning materials and other student services. Equally, apart from the low PC ratio, the students considered the campus networks slow and unstable (Kashorda and Waema, 2014). Table 1 summarizes the status of existing and targeted ICT infrastructure in Kenyan universities to support e-learning.

Table 1

Current and Recommended ICT Infrastructure in Kenyan Universities - Critical Sub-Indicators and Targets

\begin{tabular}{|l|l|l|}
\hline Sub-indicator & Sub-indicator value (2013) & Target for 2015 survey \\
\hline $\begin{array}{l}\text { Internet bandwidth per } \\
1,000 \text { students }\end{array}$ & $4.0 \mathrm{Mb} / \mathrm{s}$ & $10 \mathrm{Mb} / \mathrm{s}$ \\
\hline PCs per 100 students & 3.8 & 10 \\
\hline $\begin{array}{l}\text { Estimated \% of students } \\
\text { who own laptops }\end{array}$ & $53 \%$ & $75 \%$ \\
\hline
\end{tabular}

(Source: KENET e-readiness data 2013)

\section{E-learning in Kenyan Public Universities}

There are 22 public universities in Kenya, each one of them having several campuses and/or constituent university colleges distributed in different parts of the country (Commission for University Education, 2014). The national ICT policy for Kenya lays the framework for e-learning considered crucial to its development and utilization (Waema, 2005; Kariuki, 2009). Similarly, according to Kenya's Ministry of Education Policy Framework for Education and Training (2012), ICT is identified as a major vehicle for teaching and learning. The policy framework therefore has identified open and distance learning (ODL) and e-learning among the priority areas. One of the strategies is to establish an Open University of Kenya and expand ODL and e-learning in existing universities by leveraging ICT to take advantage of ICT infrastructure within the country.

E-learning initiatives have been introduced in most of the public universities in Kenya though on a limited scale, most of them being at the early stages. As explained in the previous section, most of the public universities are using e-learning in blended mode due to implementation challenges. Among the universities that have started implementation of e-learning include University of Nairobi, Kenyatta University, Moi University, Jomo Kenyatta University of Agriculture and Technology and Egerton University. However, according to E-Readiness Survey of Kenyan Universities (2013) Report, only 11\% of students in Kenyan universities are taking their courses using e-learning in blended mode (Kashorda and Waema, 2014). Among the key strategies of the Kenya Vision 2030 on education is introducing e-learning and blended learning as a way of improving both access and quality of education in Kenyan Universities (NESC, 2007).

This work is licensed under a $\underline{\text { Creative Commons Attribution } 4.0 \text { International License. }}$ 
The review of literature has further revealed that very few studies on challenges of implementation of e-learning have been carried out in Kenya especially in the context of public universities. This study will therefore bridge the gap that exists in the current knowledge on challenges on implementation of e-learning in the Kenyan context by adding onto the pool of knowledge on the subject. Where there is similarity in results, we have done triangulation with the literature review. The findings from this study will serve as an important reference material and a basis for further research by academicians and researchers at both national and international front.

\section{Methodology}

The work described in this paper was carried out in three leading Kenyan public universities between the years 2010 and 2012. The aim of the study was to investigate the challenges hindering the implementation of e-learning in Kenyan public universities. This study employed a mixed methods descriptive research design. The major purpose of descriptive research is description of the state of affairs as it exists (Kombo and Tromp, 2006). Leedy and Ormrod (2001) point out that in a descriptive study, the researcher can use the results obtained from the sample to make generalizations about the entire population only if the sample is truly representative of the population. Descriptive research design was appropriate for this study because the study involved collection of quantitative and qualitative data from a varied number of respondents by interviewing or administering a questionnaire to a sample of individuals. The sample size of the study was 148 respondents drawn from three Kenyan public universities. The respondents comprised of 125 lecturers, 14 ICT/ e-learning staff, 6 members of university management and 3 directors in charge of e-learning, one from each of the three universities.

Purposive sampling was used to select the three universities as study sites because these universities are public universities located in different regions of the country and are already implementing e-learning. Stratified proportionate sampling technique was used to group up lecturers using e-learning in teaching into schools from each of the three universities. Out of these groups, $30 \%$ of the lecturers were randomly picked in each of the three universities using simple random sampling to obtain a representative sample. Purposive sampling was equally used to draw samples from the ICT/e-learning staff, directors of e-learning and university management from the three universities due to their unique roles of e-learning technical support, administrative issues and policy issues respectively in the implementation of e-learning. The management of the universities and directors in charge of e-learning were also considered as key informants in this study.

Data was gathered by administering a structured questionnaire with open-ended questions to the lecturers and ICT/ elearning staff. A semi-structured interview was carried out with directors of

This work is licensed under a Creative Commons Attribution 4.0 International License. 
e-learning and members of university management. The questionnaire and interview schedule had similar questions. The two main questions were:

(a) What challenges do public universities in Kenya face that hinder the successful implementation of e-learning?

(b) What are your recommendations for addressing these challenges?

However, it was possible to probe further during the interview when need arose. Documentary analysis was also a critical element in the data collection. Additional secondary data were collected through document analysis from university reports, strategic plans, university policies, government documents and relevant journals of earlier researches.

The data collected from questionnaire was analyzed quantitatively by categorizing and coding. After coding, SPSS statistical analysis software was used to analyse the data. Qualitative data from interviews was organized into relevant themes and concepts, then descriptions and discussions given. After analysis of both quantitative and qualitative data, it was interpreted by use of descriptive narrations. The data analysis process also included the comparison between the responses and relevant documents to augment the quality of information accross the whole data set.

\section{Results and Discussion}

In this section, we present the results emerging from this study and discuss the findings. The study collected data by using data collection tools that were complementary to each other which included questionnaire, interview schedule and document analysis. The data collected using the questionnaire and interviews was analyzed separately for their relevance or irrelevance with research literature. The respondents generally acknowledged that there are several challenges that hinder the implementation of e-learning in Kenyan public universities. Out of the 148 respondents targeted in this study, 127 (91\%) respondents completed and returned the questionnaire while all the 6 members of university management and 3 directors were interviewed successfully and their responses recorded.

The results arising from analysis of questionnaire are presented in Table 2.

This work is licensed under a $\underline{\text { Creative Commons Attribution } 4.0 \text { International License. }}$ 
Table 2

Challenges Identified by Respondents as Hindering Implementation of E-Learning

\begin{tabular}{|l|c|}
\hline $\begin{array}{l}\text { Challenges identified as hindering the implementation } \\
\text { of e-learning }\end{array}$ & No. of Respondents \\
\hline Inadequate ICT and e-learning infrastructure & $117(92 \%)$ \\
\hline Financial constraints & $110(87 \%)$ \\
\hline Lack of affordable and adequate Internet bandwidth & $93(73 \%)$ \\
\hline Lack of operational e-learning policies & $108(85 \%)$ \\
\hline $\begin{array}{l}\text { Lack of technical skills on e-learning and e-content } \\
\text { development by the teaching staff }\end{array}$ & $90(71 \%)$ \\
\hline $\begin{array}{l}\text { Lack of interest and commitment among the teaching } \\
\text { staff to use e-learning }\end{array}$ & $84(66 \%)$ \\
\hline Amount of time required to develop e-learning content & $100(79 \%)$ \\
\hline
\end{tabular}

Number of respondents: $(\mathrm{N}=127)$

The results from the interview were recorded separately and later merged with quantitative results for the purpose of interpretation and discussion. In mixed methods studies, investigators intentionally integrate or combine quantitative and qualitative data rather than keeping them separate. This integration can be achieved by reporting results together in a discussion section of a study, such as reporting first the quantitative statistical results followed by qualitative quotes or themes that support or refute the quantitative results (Creswell \& Plano Clark, 2011).

The different tools of data collection, namely questionnaire and interviews, enabled the gathering of data that are complementary with each other and helped to validate, deny or enrich the results for the purpose of wider interpretation.

The results on Table 2 show that $92 \%$ of the respondents identified inadequate ICT and e-learning infrastructure as one of the challenges hindering the implementation of e-learning in Kenyan public universities. All the respondents interviewed equally concurred that inadequate ICT and elearning infrastructure is a major challenge hindering the implementation of e-learning. Below are some of the comments from the respondents interviewed:

"..some schools in our university do not even have an equipped computer lab...".

"...majority of staff and students in arts, humanities and business related programmes do not have access to computers and internet at school, hence cannot access e-learning platform”.

Table 2 also shows $87 \%$ of the respondents consider financial constraints as a challenge hindering the implementation of e-learning. Six respondents who were interviewed also believe financial 
constraints has hindered successful implementation of e-learning in Kenyan public universities. This was evident from the following comments by the respondents:

“...our public universities do not consider e-learning among the key investments to be prioritized in funding due to budget constraints".

“...government funding to public universities in Kenya has been dwindling gradually over the years, hence forcing our universities to reduce funding for some of the projects including e-learning".

It can also be observed from Table 2 that $73 \%$ of the respondents are of the opinion that lack of affordable and adequate Internet bandwidth is a hindrance towards implementation of e-learning in Kenyan public universities. Among those respondents who were interviewed, seven identified lack of affordable and adequate Internet bandwidth as one of the challenges hindering implementation of e-learning. This was evident from the following response from a respondent:

"...though the government subsidises the cost of bandwidth for public universities, the current subsidized cost of $\$ 200$ per Mbps is still expensive, hence public universities cannot afford to procure adequate bandwidth to support the entire student and staff population access e-learning".

Further, it is evident from Table 2 that $85 \%$ of the respondents indicated that lack of operational e-learning policies is among the challenges hindering the implementation of e-learning in Kenyan public universities. Five of the key informants in this study who were interviewed also believe that lack of operational e-learning policies has hindered successful implementation of elearning. Below are some of the comments from respondents:

"...though the university has an e-learning policy, implementation of the policy has been hampered by lack of adequate funds and relevant e-learning infrastructure".

"...the e-learning policy of our university has been in draft version for the last three years, therefore it's not yet operational".

Results in Table 2 also show that $71 \%$ of the respondents consider lack of technical skills on elearning and e-content development by the teaching staff as hindering implementation of elearning in Kenyan public universities. Six of the respondents who were interviewed also alluded that lack of technical skills on e-learning and e-content development by the teaching staff is a challenge hindering the implementation of e-learning. Below are some of the comments from respondents:

This work is licensed under a Creative Commons Attribution 4.0 International License. 
"...out of the over 1000 teaching staff in our university, only 250

have successfully undergone training in e-learning skills, majority

still lack skills on use of e-learning in teaching and learning”.

".. most of those lecturers who do not have a background in ICT

lack the necessary skills required to develop e-content ".

Looking further at the results in Table 2, it is notable that $66 \%$ of the respondents pointed out lack of interest and commitment among the teaching staff to use e-learning as another challenge hindering the implementation of e-learning in Kenyan public universities. However, only 4 respondents interviewed also pointed out lack of interest among the teaching staff to use elearning as a challenge hindering the implementation of e-learning. A respondent commented that "...some lecturers fear that implementing e-learning can render some of them redundant, hence they lack commitment towards using e-learning as an alternative approach to teaching".

Lastly Table 2 indicates that $79 \%$ of the respondents believe the amount of time required to develop elearning content is also one of the challenges hindering the implementation of elearning in Kenyan public universities. Seven of the key informants in this study who were interviewed also acknowledged that the amount of time required to develop e-learning content is a hindrance to implementation of e-learning. A respondent pointed out that "...due to shortage of teaching staff, lecturers are so busy teaching many courses, hence lack the time to convert their courses from hardcopy to digital format".

\section{Challenges Hindering the Implementation of E-Learning}

This study set out to explore challenges experienced by Kenyan public universities in implementation of e-learning. The discussions on challenges hindering the implementation of elearning in Kenyan public universities are elaborated in this sub section.

\section{Inadequate ICT and e-learning infrastructure.}

The study revealed that inadequate ICT and e-learning infrastructure is one of the major challenges hindering the implementation of e-learning in Kenyan public universities. It came out quite clearly that infrastructure plays a key role in the implementation of e-learning. The respondents cited infrastructure like computers, network and internet connectivity, and computer labs as inadequate in most public universities to support the high numbers of students who want to access e-learning. There was agreement however that most public universities have made some progress in improving their ICT and e-learning infrastructure in the last few years. ESIB (2003) also points out that the institution providing e-learning must provide adequate technological infrastructure, including network connections and computers, and technical support for both students and staff.

This work is licensed under a Creative Commons Attribution 4.0 International License. 


\section{Financial constraints.}

The study also revealed that financial constraints is one of the challenges hindering the implementation of e-learning in Kenyan public universities. Implementation of e-learning is generally expensive for an average university at the initial startup stages. Inadequate financing of e-learning is therefore a major barrier to its successful implementation in Kenyan Universities. Though it was noted that Kenyan public universities make yearly budgetary allocations for elearning implementation, it was evident that these allocations are inadequate to carry out all important e-learning activities like training of staff on e-learning, maintenance, e-content development, Internet bandwidth and e-learning infrastructure development. It also emerged that most ICT and e-learning related projects in public universities rely on donor funding. Most Kenyan public universities do not prioritize e-learning in their budgetary allocations. Huynh et al (2003) found out that budgetary restriction is a primary concern for institutions. According to Kashorda and Waema (2014), on average, Kenyan universities were spending only $0.5 \%$ of their total recurrent expenditures on Internet bandwidth.

\section{Lack of affordable and adequate Internet bandwidth.}

Moreover, we found out in this study that public universities in Kenya lack affordable and adequate Internet bandwidth, hence it is one of the challenges hindering implementation of elearning. The respondents indicated that though the cost of bandwidth in most public universities has gone down following the introduction of bandwidth subsidy by the government through the Kenya Education Network (KENET) and the arrival and operationalization of the undersea backbone fibre optic cables in Kenya in the year 2012, the cost of Internet bandwidth is still high, hence currently universities cannot afford to procure adequate internet bandwidths. Faster internet connectivity is critical to an institution using e-learning to support teaching and learning. According to the E-Readiness Survey of Kenyan Universities (2013) Report, the current price of $\$ 160$ per Mb/s was still a high price in comparison to developed countries.

\section{Lack of operational e-learning policies.}

On the other hand, the study also revealed that lack of operational e-learning policies is another challenge hindering the implementation of elearning in Kenyan public universities. It was observed that some Kenyan public universities don't have an e-learning policy and in cases where a policy exists, it's not operational. Most Kenyan public universities are unable to implement their elearning policies due to budgetary constraints and lack of the necessary e-learning infrastructure. A policy framework on e-learning is critical to the success of implementation of elearning in any given institution. In developing the appropriate e-learning policies, the core business of the university must take the center stage so as to ensure that e-learning puts the university on a competitive edge. Appropriate and operational e-learning policy is critical to the success of e-learning implementation. Awidi (2008) pointed out that the universities must have clearly defined strategic plans that spell out e-learning policies and implementation strategies.

This work is licensed under a Creative Commons Attribution 4.0 International License. 
Catherall (2005) also established that most Kenyan public universities have no ICT and elearning policies of any sort or where it is available, it is still in draft form.

\section{Lack of technical skills on e-learning and e-content development by the teaching staff.}

The study further reveals that lack of relevant technical skills on e-learning and e-content development by the teaching staff is a challenge hindering implementation of e-learning in public universities. This was attributed to inadequate or lack of training in e-learning skills among majority of the teaching staff. It was noted that only a few of the teaching staff have been adequately trained on e-learning skills. Though some of the teaching staff have basic computer literacy skills, these skills may not be adequate for them to use e-learning in teaching as well as developing e-content, hence need for training. Wanyembi (as cited by Tarus, 2011, p. 138) found out in a survey done in Kenya that most of the academics in universities have low ICT and elearning skills because most of them were trained in the absence of ICT environment. E-learning skills for lecturers and relevant e-content are critical components necessary for successful implementation of e-learning.

\section{Lack of interest and commitment among the teaching staff to use e-learning.}

We found out that lack of interest and commitment among majority of the teaching staff to use elearning in teaching in public universities is another challenge hindering the implementation of elearning. This was attributed to lack of motivation among the teaching staff who perceive conversion of their courses to e-content as extra work with no additional pay. Fear of loss of jobs as a result of implementation of e-learning was also cited as a cause for lack of interest and commitment to use e-learning by the teaching staff. Khan, Hasan and Clement (2012) also found out that if teachers want to successfully use technology in their classes, they need to possess a positive attitude to the use of technology.

\section{Amount of time required to develop e-learning content.}

Lastly, the study revealed that creating e-content takes a longer time, hence hindering the implementation of e-learning in public universities. It came out clearly that most teaching staff are busy with routine teaching and research tasks, hence do not have adequate time to convert their courses from hard copy to e-content. However, on the other hand, the benefit is once a course has been developed in digital format, it is easier and less time consuming to maintain and update. Tarus (2011) found out that developing one complete e-learning course requires a longer period of time as well as resources such as computer and reliable internet connectivity.

This work is licensed under a Creative Commons Attribution 4.0 International License. 


\section{Recommendations}

The findings of this study indicates that implementation of e-learning in Kenyan public universities is facing many challenges. Gichoya (2005) in his analysis of factors for successful implementation of ICT projects in government points out that success factors are occurrences whose presence or absence determines the success of an ICT project. He points out that their absence can cause failure and their presence can cause success. In the context of this study, the presence of challenges enumerated in the results and discussion section of this paper are the main reasons for failures in implementation of e-learning in Kenyan public universities. This study therefore recommends that Kenyan public universities should address these challenges as a prerequisite to successful implementation of e-learning.

Among the possible strategies that the respondents recommended that public universities could undertake to address the challenges of implementation of e-learning include:

(a) Expansion of ICT and e-learning infrastructure to facilitate access to e-learning by students, teaching staff and other stakeholders through allocation of more resources towards ICT and e-learning infrastructure development. Availability of computers, laptops, networks and other relevant infrastructure will improve accessibility to e-learning.

(b) Prioritization of ICT and e-learning in budgetary allocations just like other core activities of the university.

(c) Internet service providers to Kenyan universities which include the government owned Kenya Education Network (KENET) should lower further the cost of Internet bandwidth to make it more affordable by universities. This can be achieved through more bandwidth cost subsidy by the government to Kenyan universities through KENET. Adequate Internet bandwidth will ensure faster Internet connectivity, hence facilitating easier access to e-learning.

(d) Formulation of appropriate and operational e-learning policies to guide the Kenyan public universities towards successful implementation of e-learning.

(e) Comprehensive training of lecturers on e-learning skills. Training of lecturers on e-learning skills is among critical determinants of successful implementation of e-learning.

(f) Collaborations and partnerships with other successful e-learning partners in a bid to acquire best practices to accelerate the implementation of e-learning as well as reduce duplication of resources. Partnerships could be in areas like development and sharing of e-content and other resources, funding, training of e-learning stakeholders, and e-learning infrastructure development. According to Utsumi (2005), the advantages of partnerships include collaboratively addressing educational and developmental issues, strengthening technical and human capacity building for teaching, learning and research.

This work is licensed under a Creative Commons Attribution 4.0 International License. 
(g) Using blended learning approach and piloting with few schools as a starting point before implementation of full scale e-learning. This recommendation is supported by Awidi (2008) who advises that developing an e-learning environment that is trusted and sustainable for higher education requires pursuing a blended approach to educational delivery, at least initially.

(h) Introduction of compulsory ICT and e-learning courses in the curricula for all students especially at the first and second year of study to equip them with ICT and e-learning skills.

(i) Making it compulsory for each student to have a laptop when reporting to the university to enhance their ICT and e-learning literacy as well as improve accessibility to e-learning. Universities can partner with leading computer manufacturers and negotiate for cheaper ways of acquisition of computers and laptops by students.

(j) Identifying a way of motivating the teaching staff to use e-learning and convert their course materials to e-content either through being given extra credit points during promotions, monetary incentives etc. Relevant and high quality e-content is vital to success of e-learning.

\section{Conclusion}

This paper has investigated the challenges hindering the implementation of e-learning in Kenyan public universities. In this study, it has emerged that implementation of e-learning in Kenya faces a number of challenges which include but are not limited to inadequate ICT and e-learning infrastructure, financial constraints, expensive and inadequate Internet bandwidth, lack of operational e-learning policies, lack of technical skills on e-learning and e-content development by teaching staff, lack of interest and commitment among the teaching staff, and longer amount of time required to develop elearning courses.

This study concludes that successful implementation of e-learning can easily be achieved if these impediments can be addressed. Based on these challenges, this paper has suggested various recommendations that Kenyan public universities can adopt towards addressing the challenges hindering the implementation of e-learning in their institutions. It is evident from the study that despite the challenges, implementation of e-learning holds a substantial opportunity for Kenyan universities to expand accessibility to higher education. The aforementioned challenges of implementing e-learning make it imperative for the universities and the government to work closely and come up with radical implementation strategies so as to meet the educational needs of the country.

This work is licensed under a Creative Commons Attribution 4.0 International License. 


\section{Acknowledgement}

The authors would like to acknowledge the partial subsidy provided by MUK-VLIR-UOS Programme. MUK-VLIR-UOS Programme is a partnership between Moi University, Kenya and the collaborating Flemish Universities of Belgium under the IUC Programme. 


\section{References}

Ariwa, E. and Rui, L. (2005). The impact of e-learning on China Education and Research (CERNET). The International J ournal of the Computer, the Internet and Management, 1-28.

Al-Ghaith, W., Sanzogni, L. and Sandhu, K. (2010). Factors influencing the adoption and usage of online services in Saudi Arabia. The Electronic J ournal on Information Systems in Developing Countries, 40(1), 1-32.

Awidi, T. (2008). Developing an e-learning strategy for public universities in Ghana. EDUCAUSE Quarterly Magazine, Volume 31, Number 2.

Balci, M., \& Soran, H. (2009). Students' opinions on blended learning. Turkish Online J ournal of Distance Education-TOJ DE, Volume 10, Number 1.

Bates, A. (2004). Why universities must change. Keynote paper to the Open University of Hong Kong. Available at: http:// www.tonybates.ca/ (Accessed September 10, 2012).

Berhanu, B. (2010). A model for an eportfolio-based reflective feedback: Case study of elearning in developing countries (PhD thesis). University of Hamburg, Hamburg.

Birch, D. \& Burnett, B. (2009). Bringing academics on board: Encouraging institution-wide diffusion of e-learning environments. Australasian J ournal of Educational Technology, 25(1), 117- 134 .

Blinco, K., Mason, J ., McLean, N. and Wilson, S. (2004). Trends and issues in e-learning infrastructure development: A White Paper for alt-i-lab. Prepared on behalf of DEST (Australia) and J ISC-CETIS (UK).

Browne, T., Hewitt, R., J enkins, M., Voce, J.,Walker, R. \&Yi, H. (2010). Survey of technology enhanced learning for higher education in the UK (p. 2010). Oxford: Universities and Colleges Information Systems Association.

Cantoni, L.M. (2004). World Conference on Educational Multimedia, Hypermedia \& Telecommunications, AACE, Norfolk, pp. 50-5.

Cox M.J . (2010) The changing nature of researching information technology in education. In Researching IT in education: Theory, practice and future directions (Eds. A. McDougall, J. Murnane, A. J ones \& N. Reynolds), pp. 11-24. Routledge: Taylor and Francis Group, Abingdon, England.

This work is licensed under a Creative Commons Attribution 4.0 International License. 
Creswell, J. W., \&Plano Clark, V. L. (2011). Designing and conducting mixed methods research. (2nd ed.). Thousand Oaks, CA: Sage.

Garrison, D. R. (2011). E-learning in the $21^{\text {st }}$ century: A framework for research and practice ( $2^{\text {nd }}$ ed.). Taylor \& Francis, New York.

Garrison, R., \&Vaughan, H. (2008). Blended learning in higher education: Framework, principles and guidelines. San Francisco: J ossey-Bass.

Gichoya D (2005). Factors affecting the successful implementation of ICT Projects in government. The Electronic J ournal of e-Governmen,t Volume 3, Issue 4, pp 175-184. Available online at www.ejeg.com (Accessed on November 10, 2013).

Gunawardena, K.D. (2005). An empirical study of potential challenges and benefits of implementing e-learning in Sri Lanka. Proceedings of the Second International Conference on eLearning for Knowledge-Based Society, 4-7 August, Bangkok.

Huynh, M.Q., Umesh, U.N. and Valachich, J . (2003). E-learning as an emerging entrepreneurial enterprise in universities and firms. Communications of the AIS, 12, 48-68.

Kariuki, G. (2009). Growth and improvement of information communication technology in Kenya [Electronic Version]. International J ournal of Education and Development using ICT. Retrieved 2nd October 2009 from http:/ / ijedict.dec.uwi.edu/ viewarticle.php?id=667\&layout=html

Kashorda, M., \&Waema, T. (2014). E-Readiness survey of Kenyan Universities (2013) report. Nairobi: Kenya Education Network.

Khan, S., Hasan, M. and Clement, C. (2012). Barriers to the introduction of ICT into education in developing countries: The example of Bangladesh. International Journal of Instruction, Vol. 5(2), pp. 61-80. Available online at http:// www.eiji.net/dosyalar/iji_2012_2 4.pdf (Accessed on November 15, 2014).

Kombo, D. K. and Tromp D. L. A. (2006). Proposal and thesis writing: An introduction. Nairobi: Paulines Publications Africa.

Leedy, P. D. and Ormrod, J . E. (2001). Practical research: Planning and design (7th Edition). Upper Saddle River, NewJ ersey: Prentice-Hall.

Li, R., \& Hart, R. (1996). What can the Word Wide Web offer ESL teachers? TESOL J ournal, 6(2), 5-10. 
Lin, N. T. (2006). The evolution of computer assisted language learning (CALL) and its teaching approaches. Proceedings of 2006 CHINA International Conference on Instruction and learning, 105-130.

Manduku, J . Kosgey, A. \& Sang, H. (2012) Adoption and use of ICT in enhancing management of public secondary schools: A survey of Kesses zone secondary schools in Wareng District of Wasin Gishu County, Kenya. Available at: http:// www.iiis.org/cds2012/cd2012sci/ eista 2012/paperspdf/ ea069vm.pdf (Accessed on November 15, 2014).

Ministry of Education Policy Framework for Education and Training (2012): Reforming Education and Training in Kenya.

Motteram, G. (2006). Blended' education and the transformation of teachers: A long-term case study in postgraduate UK higher education. British J ournal of Educational Technology 37, 1, 17- 30 .

Nawaz, A. and Kundi, G. M. (2010). Demographic implications for the user-perceptions of elearning in higher education institutions of N-W.F.P, Pakistan. The Electronic J ournal on Information Systems in Developing Countries, 41(5), 1-17.

NESC (2007). Kenya Vision 2030: A globally competitive and prosperous Kenya. National Economic and Social Council of Kenya.

Oye, N. D., Salleh, M., \& Iahad, N. A. (2011). Challenges of e-learning in Nigerian university education based on the experience of developing countries. International J ournal of Managing Information Technology, 3(2), 39-48.

Pal, J . (2006). Early-stage practical of Implementing computer-aided education experience from India. Proceedings of the $4^{\text {th }}$ IEEE International Workshop: Technology for Education in Developing Countries, Tumaini University, Iringa, TEDC, 10-12 J uly, IEE Computer Society, Los Alamitos.

Rhema, A. and Miliszewska, I. (2010). Towards e-learning in higher education in Libya. Issues in Informing Science and Information Technology, Volume 7, 423 - 437.

Salmon, G. (2004). E-moderating: The key to teaching and learning online (2nd ed.) Oxfordshire: Taylor \& Francis Books Ltd.

Sangrà, A., Vlachopoulos, D., \& Cabrera, N. (2012). Building an inclusive definition of e-learning: An approach to the conceptual framework. International Review of Research in Open and Distance Learning, 13(2), 145-159.

Ssekakubo, G., Suleman, H. \&Marsden, G. (2011). Issues of adoption: Have e-learning 
management systems fulfilled their potential in developing countries? In Proceedings of the South African Institute of Computer Scientists and Information Technologists Conference on Knowledge, Innovation and Leadership in a Diverse, Multidisciplinary Environment (pp. 231- 238). Cape Town, South Africa.

Takalani, T. (2008). Barriers to e-learning amongst postgraduate black students in higher education in South Africa. Thesis presented in partial fulfillment of the requirements for the degree of Master of Philosophy (Information and Knowledge Management), Stellenbosch University, Stellenbosch.

Tarus, J . (2011). Adoption of e-learning to support teaching and learning in Moi University. Thesis presented in partial fulfillment of the requirements for the degree of Master of Philosophy (Information Technology), Moi University.

Tedre, M., Bangu, N., \& Nyagava, S. I. (2009). Contextualized IT education in Tanzania: Beyond standard IT curricula. J ournal of Information Technology Education, 8, 101-124.

Touray, A., Salminen, A. and Mursu, A. (2013). ICT barriers and critical success factors in developing countries. The Electronic J ournal on Information Systems in Developing Countries, 56(7), 1-17.

Unwin, T. (2008). Survey of e-Learning in Africa. Based on a Questionnaire Survey of People on the e-Learning Africa Database in 2007.

Utsumi, Y. (2005). Connect the World official launch. Available at http:// www.itu.int/ partners/pdf/SG_preso.pdf (Accessed on J anuary 17, 2013).

Uys, P.M., Nleya, P. N \& Molelu, G.B (2003). Technological innovation and management strategies for higher education in Africa: Harmonizing reality and idealism. Educational Media Intenational, Volume 40. Routledge, UK.

Waema, M. T. (2005). A brief history of the development of an ICT policy in Kenya. In E. F. Etta \& L. Elder (Eds.), At the crossroads: ICT policy making in East Africa (pp. 25-43). Nairobi: East African Educational Publishers Ltd.

Wanjala, M. S., Khaemba, E. N. \&Mukwa, C.. (2011). Significant factors in professional staff development for the implementation of ict education in secondary schools: A case of schools in Bungoma District, Kenya. International J ournal of Curriculum and Instruction, Vol. 1(1), pp. 30-42, April 2011.

Zake, J . (2009), Challenges to e-learning in developing communities of Africa. Available at: http:// digitallearning.in (Accessed on August 28, 2013). 
(C) Tarus, Gichoya, and Muumbo

\section{Athabasca University $\mathbf{A}$}

(c) 